\title{
KAŞAR: EKOLOJiK BIR KENT IMGESI ÖRNEĞi
}

\author{
Kashar: An Example of an Ecological City Image
}

Cevdet AVCl*

\section{öz}

Bu çalışmada hayvansal bir gıda olan kaşarın doğa-kültür etkileşimine bağlı olarak ortaya çıkışı ve ekolojik bir kent imgesi örneğine dönüşümü ele alınmaktadır. Çalışmada, Kars kaşarı bağlamında kültürel küreselleşme karşısındaki yerelin öne çıkma süreçlerinde kent imgelerinin rolü ve önemini tartışmak amaçlanmaktadır. Konuyla ilgili yazılı ve elektronik kültür ortamından doküman analizi tekniğiyle veri toplanmış ve incelenmiştir. 2011 yılında Boğatepe (Zavot) köyünde Türkiye'nin ilk peynir müzesi, bir ekomüze olarak faaliyete geçmiştir. 2015'te coğrafi işaret tescili alan kaşar, Kars'ın kültür ekonomisine katkı sağlamaktadır. Çalışmada elde edilen bulgulara göre kaşar, çağrışım seviyesinde Kars'la özdeşleşerek bir kent imgesine dönüşmüş ve Kars'ın tanıtım araçlarından birisi olmuştur. İnsanın doğayla bütünleşme çabalarının arttığı 21. yüzyılda ekolojik ürün ve üretim yerleri, bu arayışa cevap vermektedir. Makalede ele alınan kaşarın, Kars'ı ulusal ve uluslararası ölçekte temsil ederek bu anlamda bir cazibe merkezi yarattığı sonucuna varımıştır. Bu durum, gelenek kökenli kent imgelerinin kültürel küreselleşme karşısında direnç oluşturma açısından oynadığı role örnek teşkil etmektedir.

Anahtar Sözcükler: kaşar, peynir, Kars, kent imgesi, ekoturizm.

\section{ABSTRACT}

In this study, the emergence of kashar, which is an animal food, due to the interaction of nature-culture and its transformation into an ecological urban image is discussed. In this study, it is aimed to discuss the role and importance of city images in the processes of coming to the fore in the face of cultural globalization in the context of Kars kashar. Data on the subject were collected and analyzed from the written and electronic culture media with the document analysis technique. In 2011, the first cheese museum of Turkey in Boğatepe (Zavot) village was opened as an ecomuseum. Kashar, registered as a geographical indication in 2015, contributes to the cultural economy of Kars. According to the findings obtained in the study, kashar became an image of the city by identifying with Kars at the level of connotation and became one of the promotional tools of Kars. In the 21st century, where human ef-

\footnotetext{
* Dr. Öğr. Üyesi. Gaziantep Üniversitesi, Fen Edebiyat Fakültesi, Türk Dili ve Edebiyatı Bölümü, Gaziantep/Türkiye. E-posta: cavci@gantep.edu.tr. ORCID ID: 0000-0003-0948-1659. 
forts to integrate with nature are increasing, ecological products and production sites respond to this search. It was concluded that the kashar in the article represented Kars on a national and international scale and created a center of attraction in this sense. This situation exemplifies the role played by tradition-based city images in creating resistance against cultural globalization.

Keywords: kashar, cheese, Kars, city image, ecotourism.

\section{Giriş}

İnsanın, doğayı ve toplumu anlama çabalarının ürünü olan bilimsel çalışmalar, 19. yüzyıldan bu yana hızla katlanarak artmıştır. Bu süreçte doğa bilimleri kendi içerisinde sistematik bir eşgüdümle bütünleşmiş ve bugün uzay teknolojilerine uzanan evreye gelmiştir. İnsanın sosyal ve fiziki çevresiyle kurduğu ilişkileri çeşitli yönlerden inceleyen sosyal bilimlerde de benzer bir süreç işlemektedir. Başta üretim-tüketim ağlarına bağlı olarak toplumsal hayatın değişen yanları, sosyal bilimlerin sürekli olarak güncellenmesine sebep olmuştur. Bu bağlamda, özellikle 19. yüzyılda Avrupa'daki sanayileşme ve kentleşme odaklı gelişmeler, sosyo-kültürel hayatı etkilemiştir. Bu süreç bir taraftan mevcut sosyal bilim alanlarının kendini güncelleme sonucunu doğururken bir taraftan da yeni bilgi alanlarının ortaya çıkmasını sağlamıştır. Bu çerçevede sosyal bilimlerde kuram, yöntem, araştırma alanı ve yeni yaklaşımlar toplumsal-kültürel hayatta ortaya çıkan yeni durum ve intiyaçlara göre şekillenmektedir. Ulaşım, iletişim ve etkileşim odaklı 20-21. yüzyıl, bu durumun anlaşılmasında önemli gelişmelerin yaşanmaya devam ettiği süreçleri içermektedir.

19. yüzyıldan bu yana toplumsal-kültürel ilerlemelere paralel olarak ortaya çıkan ve şekillenen sosyal bilim dallarından birisi halk bilimidir. Bu yüzyıldan itibaren sosyal bilim dalları benzer süreçlerde gelişim göstermiştir. Halk bilimi çalışmalarında insan, toplum ve kültür denklemi; köy, kent, medya ve/veya iletişim odaklı incelenmiştir. Müstakil bir bilim dalı olan halk bilimi bu süreçlerin yansıması olarak temel kavramlarını tartışmış ve güncellemiştir. "Halk" ve "halk bilimi" kavramları bu çerçevede ele alınırken (Dundes, 1998: 138-153), bir taraftan da alanın konuları ile araştırma yöntem ve teknikleri, köy ve köy çevresinden kent merkezine doğru genişlemiştir. Sanayi Devrimi sonrası ortaya çıkan kentleşme süreçleri, yeni meslek grupları ve kültür kümelerinin doğmasını sağlamıştır. ilerleyen süreç halk biliminin odak noktalarından birisini, kent folkloru çalışmaları olarak ortaya çıkarmıştır. 
Kentleşme süreçleriyle birlikte teknolojik gelişmelerin de etkisiyle kültürün üretim, paylaşım ve dolaşım ortamları değişmiştir. Böylece Batı kaynaklı kültürel küreselleşme baskısı karşısında Türk kültürünün yerelden ulusala ve evrensele taşınma çabaları kent merkezli halk bilimi çalışmalarının gündemine girmiştir. Bu çerçevede kent ve imge çalışmalarının söz konusu çalışmalar içerisinde önemli bir yeri vardır. Nebi Özdemir'in (2012: 109) de ifadesiyle imge araştırmaları çok yönlü etki ve işleve sahip bir inceleme alanına dönüşmüştür. Kent imgelerinin ön plana çıkartılması, kentin tanıtımıyla birlikte ekonomik katma değere yansımaktadır. Coğrafi işaret sistemiyle de tescillenen söz konusu kent imgesinin özelliğine bağlı olarak kültür turizmi, inanç turizmi, mutfak turizmi, sağlık turizmi gibi pek çok alanda önemli sonuçlar ortaya çıkmaktadır. Diğer taraftan kentteki ilgili sektörlerde var olan iş kapasitesi ve istihdamı gelişmekte; yörenin geleneksel ürün, üretim ve üretici ağı genişlemektedir. Bu bağlamda bir kent imgesinin ortaya çıkmasında üç aşamalı bir süreç gerekmektedir. Bunlar; "kültürel belleğin oluşturulması, kültürel imgelerin yaratımı ve kültürel imgelerin gösterimi” (Özdemir, 2012: 112) şeklindedir. Bu çerçevede makalenin konusunu, hayvansal bir ürün olan Kars kaşar peynirinin bir kent imgesine dönüşümü teşkil etmektedir. Makalede hayvansal bir ürünün geleneksel üretim teknikleriyle yüz yıllık süreçten bugüne gelmesi ve yerelden ulusala taşınarak kent imgesi işlevi kazanmasının incelenmesi amaçlanmaktadır. Konuyla ilgili yazılı ve elektronik ortamdan yapılan taramada doküman analizi tekniğiyle veriler incelenmiştir. Makalede öncelikle kent imgesi kavramı üzerinde durularak gıda ürünlerinin kent imgesine dönüşümü üzerinde durulmuş, daha sonra Kars kaşarının bir peynir türü olarak geleneksel üretimi incelenip coğrafi işaretleme yoluyla Kars kültür ekonomisine katkısı ve hayvansal bir gıdanın kent imgesine dönüşümü değerlendirilmiştir.

\section{Kent Imgesi ve Beslenme Kültürü}

21. yüzyılda dijital kültür ortamının da etkisiyle hızlanan kültürün küreselleşme süreçleri, kentlerin çeşitli özellikleriyle tanınma ve ön plana çıkma çabasını arttırmaktadır. Halk bilimi çalışmalarında kent imgelerini ön plana alan araştırmalar, uygulamalı halk bilimi çerçevesinde değerlendirilmektedir. Yapılan çalışmalara bakıldığında Türkiye'deki kentler ve imgeler konusunda geniş bir veri alanının oluştuğu görülmektedir. Güzel ve Kuşdemir'in (2018: 219) de değerlendirmelerine göre; küreselleşme karşısında, özellikle 2000'li yıllardan itibaren hem var olan kent imgelerinden faydalanma hem de yeni kent imgeleri üretme konusunda arayışlar hızlanmıştır. Uygulamalı 
halk bilimi alanında yapılan çalışmalar, bu kent imgelerinin daha geniş alan ve kitlelere ulaştırılmasında kaynak teşkil etmektedir.

Türkiye'de geleneksel üretim-tüketim biçimlerinin varlığını sürdürmesi kent imgeleri bakımından özgün bir yapının oluşmasını sağlamaktadır. Diğer taraftan Türkiye'nin zengin bitki örtüsü ile tarihî ve kültürel yapısı da kent imgesi oluşum süreçlerini olumlu anlamda etkilemektedir. Özdemir (2011: 47) kent imgesini "doğal, tarihî ve kültürel kent belleğinden beslenilerek tasarlanan yeni somut ya da soyut yaratmalar/görüntüler" olarak tanımlar. Buna bağlı olarak meyve, yayla, göl, dağ, hayvan gibi doğal unsurlar; antik kalıntılar; Selçuklu ve Osmanlı Dönemi eserleri gibi tarihî yapılar ve mutfak kültürü, el sanatları, oyunlar gibi kültürel unsurlar Türkiye'de kent imgesi olarak ön plana çıkabilmektedir. Kentlerin oluşum ve gelişim süreçlerinde "meşhurlaşmış kültürel verimler" (Oğuz, 2002: 59) şeklinde de tanımlanan kent imgeleri, kent belleğine yaslanan bir yapıya sahip olmalıdır. Kentbilim Terimler Sözlüğü’nde (1980) kent imgesi, “Tasarımı, düzenlenişi, görünümü ve yapılarının yapıtasarcılık özellikleriyle, bir kentin insanda bıraktığı izlenim." şeklinde tanımlanmaktadır. Bu tanımlamada kent imgesinin fiziki boyutu ön plana çıkmaktadır. Buna paralel olarak Kevin Lynch (2014: 8) kent imgelerinin "kimlik, yapı ve anlam" özelliklerini barındırması gerektiğini ifade eder.

Çeşitli yönleriyle ele alınan kent imgelerinin en belirgin özelliğinin bir bölgeyi temsil kabiliyeti olduğu söylenebilir. "Imgelerin temel niteliği, bağlantılı olduğu kültürü ya da yöreyi, kenti çağrıştırması veya üzerinde taşımasıdır." (Güzel ve Kuşdemir, 2018: 208). Böylece kültürel yapıyı temsil ederek yörenin tanıtım aracına dönüşmektedir. İmgeler ulusal ve uluslararası boyutta dünyaya açılan "şehrin dili" (Barthes, 1993: 176), rolünü üstlenmektedir. Bu bakımdan "oluşum/yayılma/yararlanma" (Oğuz, 2004: 4) şeklinde formüle edilen kent imgelerinin teşekkülünde kentin dışa açılma yolları da önem taşımaktadır. Ticaret ve turizm gibi etkenler, kentin ulusal ve uluslararası ölçekte tanınırlığında yöresel unsurların ön plana çıkmasına katkı sağlamaktadır. Bu süreçlerde kent imgelerinin sunumunda yerel yönetimlerin, çeşitli kurum ve kuruluşların da çabası söz konusudur. "Kentlerin ana imgeleri, öteki ya da ötekilerle karşılaşılan her mekân ve ortamda yer almakta ve gösterilmektedir. Bu ana imgelerin yanında daha çok yemek, dans, müzik, el sanatları gibi kültürel alanlarda belirginleşen yan imgeler, daha özel mekân ve ortamlarda gösterilmekte ve paylaşılmaktadır." (Özdemir, 2012: 119). Kendiliğinden veya bir tasarım sonucu ortaya çıkan kent imgesi, kent markasıyla birlikte algılanmaktadır. Kent imgesine dönüşebile- 
cek unsurlar içerisinde, kentin "sahip olduğu coğrafî özellikler ve buna bağlı olarak ortaya çıkan iklim, bitki örtüsü, bölgeye has yetiştirilen ürünler ve hayvanlar" (Kuzay Demir, 2015: 502) da yer almaktadır.

Makalede incelenen kaşar peyniri, doğal şartların ürünü olarak ortaya çıkmakla birlikte üretim biçimi ve yöre mutfağındaki yeri bakımından kültürel nitelik taşımaktadır. Beslenme, insanlık tarihine paralel olarak gelişmiş ve kültürün önemli parçalarından birisi olmuştur. Tarım ekonomisiyle birlikte doğan toplumun, köy ve kent yapısı içerisinde beslenme kültürü karmaşık bir zincire dönüşmüştür. Bu çerçevede barınma alanlarında mutfak, beslenme için gerekli olan araç-gereç ve üretimin sağlandığı; aynı zamanda ev içi sosyal organizasyonun merkezinde kompleks bir alan olmuştur (Nahya, 2012). Gıda, beslenme ve mutfak içerisinde çeşitli fonksiyonları barındıran önemli kültürel yapılar olarak görülmektedir. Durukan'a göre beslenme;

Toplama, hazırlama, pişirme, tüketme konularındaki detaylar ve farklılıklar nedeniyle toplumlara kimliğini kazandıran bir unsur, açlık ve yoksulluk açısından bakıldığında, paylaşımı konusundaki uygulamalar nedeniyle siyasi bir araç, obezite düşünüldüğünde ekonomik bir kaynaktır. Sembolize ettiklerine bakıldığında tabudan, zenginliğe kadar uzanan bir yelpazenin parçası olan gıda sosyal dayanışmayı destekleyen, sosyal kontrolün bir parçası olabilen de bir mekanizmadır. Kişilerin içinde bulundukları gruba kendilerini ait hissetmelerini sağlayan, onlara kimlik kazandıran bir araçtır (2013: 48).

Tarihsel süreçte beslenme kültürünün gelişmesinde, insanla doğa arasındaki ilişki temel belirleyici unsur olmuştur. Bir bölgenin coğrafi konumu, iklim şartları ve bitki örtüsü; hayvansal ve tarımsal yapının şekillenmesini sağlamaktadır. Bu zemin üzerinde şekillenen beslenme kültürü açısından geleneksel üretim ve tüketim biçimleri; bir bölgenin dil, giyim-kuşam ve oyun unsuru örneklerinde olduğu gibi özgün nitelikler taşımaktadır. Bu bağlamda geçmişte olduğu gibi 21. yüzyılda da kentlerin ve kültürlerin kimliği doğayla iç içe oluşmaktadır. Sanayi üretimine bağlı olarak ortaya çıkan ürün ve içerikler; tarihsel, kültürel zenginlik ve özgünlük karşısında gücünü kaybetmiştir. Bu noktada kentlerin özgünlüğünü vurgulayan önemli araçlardan birisi coğrafi işaretleme sistemidir. Coğrafi işaretleme sistemi ekonomik ve kültürel işlevleri olan özgünlük ve farklılıkları belirleyen bir yöntemdir. Bu sistem içerisinde kültürel bellek, eser ve ürün açısından önemli bir veri alanı sağlamaktadır. Sürdürülebilir kalkınma ve kültür arasındaki ilişkiyi değerlendiren Özdemir’e göre; “Eskiden olduğu gibi bugün de kültürel bellekten 
hareketle geleceği yaratanlar, özgün ve farklı olabilirler. Bu nedenle bütün yaşam alanlarında kültürü, kültürel belleği/mirası ve yaratıcılığı önemseyen toplumlar, geleceğin gelişmiş toplumları olacaklardır." (2012: 78). Bu bağlamda coğrafi işaret bakımından Türk mutfak kültürü, zengin bir veri alanı oluşturmaktadır. Türk mutfağı dünya mutfak kültürü içerisinde çeşitlilik ve lezzet bakımından önemli bir yer işgal etmektedir. Türk kültürünün tarihsel olarak doğayla iç içe olması bu durumu etkileyen olumlu faktörlerden birisidir. Tarım ve hayvancılık, "beslenme zincirinde et, yağ, süt, yumurta ve tahılın çokça olması" (Durusoy, 2017: 46) sonucunu doğurmuştur. Ayrıca dinamik kültür yapısı farklı toplumlarla da mutfak kültürü alışverişini sürekli kılmaktadır.

Bu geri plan üzerinde şekillenmiş olan Türk mutfağının zengin içeriği, coğrafi işaret sistemiyle yöresel olarak pek çok gıda ürünün ön plana çıkmasını sağlamaktadır. Özellikle mutfak kültürüne bağlı olarak öne çıkan gıda ürünleri, çevresinde kültürel belleği de barındıran diğer "geleneksel alanların bütünleyicisi" (Fidan ve Özcan, 2019: 66) olma işlevini yerine getirmektedir. Bunun sonucu olarak da deniz turizmi, inanç turizmi, sağlık turizmi gibi başlıkların arasına gastronomi turizmi de eklenmiştir. iletişim ve ulaşım imkânlarının artması, ilgili ürünün ait olduğu yörede tüketilmesini veya üretiminin doğal ortamda görülmesini kolaylaştırmıştır. Kent ekonomilerine alternatif bir turizm modeli olarak katkı sağlayan gastronomi turizmi, yerel yönetimlerin öncelik verdiği alanlardan birisi olmaktadır. Bu çerçevede "coğrafi işaretli ürün sayılarıyla gastronomi turizmi arasında doğru orantı" (Durusoy, 2017: 71) gözlenmektedir. Bu süreç markalaşma ve sektörel ilerleme açısından da kentlerin gelişimine önemli katkı sağlamaktadır. Coğrafi işaret sisteminin ilgili sektörlere bağlı olarak ekonomik getirileri, yörede istihdam başta olmak üzere pek çok katma değeri ortaya çıkarmaktadır. Diğer taraftan bu yolla farkındalık oluşan ve sosyo-ekonomik hayata dâhil olan geleneksel üretim biçimleri, somut olmayan kültürel mirasın da korunmasını sağlamaktadır. Makalede ele alınan Kars kaşarının ve diğer yan ürünlerinin yapılış örneğinde olduğu gibi, geleneksel bilginin kuşaklar arasında aktarımı o ürünün kültür ekonomisindeki karşılığıyla ilişkilidir. Geleneksel bilginin kuşaklar arasında taşınması, kültürel miras yönetimi ve sürekliliğine bağlıdır. Beslenme ve mutfak kültürü, kentleşme ve fabrikasyon ürün karşısında en fazla etkilenen alanlardan birisidir. Bu süreci tersine çevirerek coğrafi işaretleme ve kent imgesi çalışmalarılla gıda ürünleri üzerinde oluşturulan farkındalık-bilinirlik, kültürel mirasın korunmasının yanı sıra insan sağlığı bakımından da önemli sonuçlar doğuracaktır. Makalede ele alınan ve bir 
peynir türü olan kaşar, bu yaklaşımla değerlendirilmesi gereken hayvansalkültürel ürünlerden birisidir. Eski bir yerleşim alanı olan Kars ve çevresinde, iklim ve bitki örtüsüne bağlı olarak hayvancılık önemli bir geçim kaynağı olmuştur. Buna bağlı olarak hayvansal ürünler, Kars beslenme kültürünün temelini teşkil etmektedir. iklim şartlarına bağlı olarak bu ürünlerin üretimi, muhafazası ve sunumu geleneksel yöntemlerle sağlanmıştır. Bugün teknolojik araç-gereçler de bu ürünlerin korunmasını ve uzak mesafelere gönderilmesini kolaylaştırmaktadır.

\section{Bir Kent İmgesi Olarak Kars Kaşarı}

Tarih öncesi devirlerden itibaren insan-doğa arasındaki ilişki; beslenme, barınma ve giyim-kuşam başta olmak üzere kültürel hayatı şekillendiren temel etkenlerden birisi olmuştur. Ekonomik üretim-tüketim kültürü bakımından toplayıcı, avcı ve tarım dönemlerinde bu süreç devam ederken Sanayi Devrimiyle birlikte Batı'dan başlayarak insan ve doğa arasındaki denge bozulmuştur. Ancak insanın ihtiyaç ve beklentilerinin doğadan bağımsız olarak karşılanması hayatın temel dinamiklerine aykırı görünmektedir. Bu bağlamda bugün insan ve doğa arasındaki dengeyi yeniden kurmaya çalışan yaklaşımlar akademik, kültürel, siyasal ve ekonomik anlamda entelektüel bir uğraşa dönüşmektedir. Özdemir'in ifadesiyle "21. asır, doğa ve kültür asrı olacaktır. Doğa ve kültür, yaşamın merkezinde yer alarak, diğer alanları biçimlendiren temel dinamikler haline gelecektir. Insanlık, doğa ve kültürden kopmanın bedellerini ödemeye ve doğal-kültürel olanla dingin yaşamanın mutluluğunu yaşamaya başlamıştır." (2012: 59, 78). Bu yaklaşıma paralel olarak kent folkloru çalışmalarında çevresel ve kültürel imgelerin ön plana çıkartılmasını da aynı çerçevede değerlendirmek mümkündür. Bu minvalde makalede ele alınan hayvansal bir gıda ürünü olan kaşar peyniri, Kars'ın kültürel belleğinde ve bugünkü ekonomik yapısı içerisinde önemli bir yere sahiptir. Türkçe Sözlük'te “kaşar” kelimesi, “Koyun sütünden yapılan, genellikle tekerlek biçiminde, sarımtırak, yağlı bir peynir." (TDK, 2005) şeklinde eksik bir tanımlamayla verilmiştir. Kaşar peyniri, aşağıda görüleceği üzere, büyükbaş hayvan sütünden, bazen de koyun sütüyle karıştırılarak yapılmaktadır. Ayrıca kaşar kelimesi sözlükte, "kaşarlanmak" olarak argo anlamıyla da yer almıştır. Buna göre kaşarlanmak, "Bir işte, bir hareketle çok deneyim kazanmak. Hoşa gitmeyen bir harekete veya bir işe alışarak artık ondan üzüntü duymaz olmak" (TDK, 2005) şeklinde geçmektedir.

Türkiye'de hayvansal gıda ürünü olarak peynir üretiminin yaygın biçimde sürdürüldüğü yörelerden birisi Kars’tır. Kars'ın coğrafi konumu, iklim ve 
bitki örtüsü büyükbaş hayvancılık açısından oldukça elverişlidir. Kars, Fahrettin Kırzıoğlu'nun verdiği bilgilere göre; “Anadolu'nun en yüksek bölgesi olan Kuzey Doğu Anadolu suları Kür ve Aras ırmaklarıyla Hazar Denizi'ne ve Çoruh vasıtasıyla Karadeniz'e karışan kesiminde olup (...) çok sert bir karasal iklime sahiptir." (1958: 1, 10). Kars adının kaynağıyla ilgili Kırzıoğlu şu tespitleri yapmaktadır: "Kars adı Anadolu'daki en eski Türkçe yer adlarından birisidir. MÖ: 130-127 yıllarında Kafkasların kuzeyinden Dağıstan bölgesinden gelerek buralara yerleşen Bulgar Türklerinin Velentur boyunun Karsak oymağının adı yöreye verilmiştir. Aynı adlı yer adlarına Anadolu'nun güneyinde de rastlanmaktadır." (1958: 15).

Tarihsel süreçte coğrafi konumuna bağlı olarak Kars, ticaret geçitleri açısında da bir merkez durumunda olmuştur. Bu bakımdan kültürel etkileşime açık bir bölgedir. Pek çok uygarlığın geçiş noktası olan Kars'ta yaşam koşullarını iklim şartları belirlemektedir. Sert iklim şartlarına bağlı olarak yeterli tarımın yapılamaması hayvancılığı ön plana çıkarmıştır. Ayrıca, kentin "tarihî birikimiyle ören yerleri ve Sarıkamış kayak pistlerinin varlığı" (Durukan, 2013: 76) turizmi canlandırmaktadır. Yörede uzun ve sert geçen kış mevsimi, kış turizminin gelişmesini sağlamaktadır. Ayrıca tarihî ve kültürel yapının zenginliği yine yöre ekonomisine önemli katkı sağlamaktadır. Bununla birlikte yörenin ekonomik yapısında bir endüstri kümesi örneği olarak kaşarcılık faaliyetleri önemli yer tutmaktadır. "Endüstrinin her ne kadar ciddi sıkıntıları olsa da, ilde bulunan kaşar peyniri endüstrisi ciddi bir üretim ve pazarlama ağına sahiptir. Sadece bu sektörün geliştirilmesi ve teşvik edilmesi bile il ve ilçeler açısından önemli bir kalkınma potansiyeli sağlayacak güce sahip görünmektedir." (Yıldız ve Alp, 2014: 257). Yörede kaşar yapımının yanı sıra bir diğer ekonomik faaliyet alanı da hayvansal ürünlerden elde edilen yemek ve giyim kültürünün çeşitliliğidir. Kış şartlarına bağlı olarak yünden elde edilen giyim eşyaları ve yün halıların ekonomik değeri vardır. Yörede geçmişte önemli bir faaliyet alanı olan dokumacılığın bugün etkisi çeşitli nedenlerle azalmıştır (Altunsabak, 2016: 29).

Makalede kent imgesi olarak ele alınan kaşar; yörede tarihsel, kültürel ve ekonomik yönüyle ön plana çıkan bir peynir türüdür. Kaşar yapımı, üretimi ve çeşitleri pek çok çalışmada ele alınmıştır. Gelibolu'nun verdiği bilgilere göre "1878 yılından sonra Türkiye'ye gelen Kafkas halklarından Terekemeler ve Ahıska Türklerinden bir kısmı, Rusya'da iken yaptıkları kaşar ve gravyer imalatını Kars'ta da devam ettirmişlerdir." (2009: 153). Konuyla ilgili olarak Durusoy, tarihte 93 Harbi olarak da bilinen Osmanlı-Rus savaşı sonrası döneme dikkat çekerek kaşar yapımın geçmişine dair şu bilgileri vermektedir: 
Bölgede bulunan isviçreli peynirciler zavotlarda (imalathanemandıra) yağ ve peynir üretimi ile uğraşırken, ineklerin ve haliyle sütlerin kalitelileştirilmesine yönelik çalışıyorlardı. Başlarda yerli ineklerden elde edilen sütler kullanılırken zamanla Rus inekleri ile simental ve İsviçre'nin damızlık ineklerinden elde edilen malakan ve zavot ineklerinin ürünleri kullanılmaya başlanmıştır. Zaman içerisinde başarılı bir üretim grafiği sonunda 1917 senesinde Rusya da gerçekleşen devrimlerden sonra Rus askerleri bölgeden çekilmeye başladılar ve isviçreli peynirciler de gittiler. Kars'ta gravyer peynirciliği artık Karapapak üreticiliğine devretmiştir (2017: 109).

Kars'ın büyükbaş hayvancılığa uygun olan iklim şartları ve bitki çeşitliliği hayvanlardan elde edilen süt kalitesini de arttırmaktadır. Bu verimlilik yörede süt ve süt ürünlerinin geleneksel yaşam biçimi içerisinde temel geçim kaynağı olmasını sağlamıştır. Kentleşme ve ulaşım imkânlarının artmasıyla birlikte kaşarcılık, kent merkezindeki işletmelerde de yaygın bir faaliyet alanı haline gelmiştir. Bugün kaşar sektörü işletmeler arasında rekabetle birlikte gelişmektedir (Yıldız ve Yıldırım, 2011: 148).

Bu bilgiler ışığında Kars'taki hayvancılık faaliyetlerine bağlı olarak sütün işlenmesiyle elde edilen kaşar peynirinin, kent çağrışımı yapacak derecede fiziksel ve kültürel nitelik kazandığını söylemek mümkündür. Bunun bilincinde olan kentteki kurum ve kuruluşlar coğrafi işaret almak için Türk Patent Enstitüsüne müracaat etmiştir. Kaşarın coğrafi işaret olarak tescili için Kafkas Üniversitesi öncülüğünde 14.02.2014 tarihinde yapılan başvuru, bu tarihten itibaren geçerli olmak üzere, 12.10.2015 tarihinde 190 tescil numarasıyla kabul edilmiştir. Böylece, Kafkas Üniversitesi koordinatörlüğünde çeşitli kuruluşlarca görevlendirilecek uzmanlardan oluşan bir komisyon tarafından üretici ve satıcılar; üretim, pazarlama ve satış dâhil olmak üzere tüm işlem evrelerinde denetime tabii tutulmaktadır. Marka tesciline göre coğrafi işaretin türü menşe adıdır. Kaşarın üretim alanı, Kars Merkez ve Ardahan Merkez, Arpaçay, Akyaka, Digor, Kağızman, Sarıkamış, Selim, Susuz, Göle, Çıldır, Hanak, Damal, Posof ilçeleri ile bu yerleşim birimlerine bağlı köy, mezra ve yaylar olarak verilmiştir (URL-3; URL-6). Kars'ta kaşar peyniri üretimi ile ilgili Mucip Demir'in (2016) hazırladığı harita şu şekildedir: 

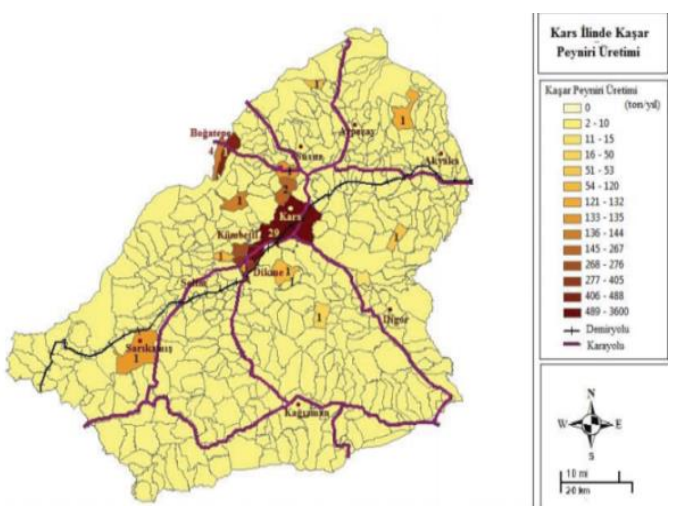

Görsel 1. Kars Illinde Kaşar Üretim Haritası (Demir, 2016: 78).

Kars kaşarının coğrafi işaretlerin korunmasına ilişkin tescil talebi ilanında kaşarın tarihçesi, tanımı ve ayırt edici özellikleri, üretim metodu ve üretimin denetlemesi konusunda ayrıntılı bilgi yer almıştır. Kars yöresinde cumhuriyetin ilk yıllarında yoğun üretim faaliyetine girilmiş ve 1927-1933 yılları arasında kırktan fazla imalathane açılmıştır. Sonraki süreçte buralardan yetişen ustalar geleneksel kaşar yapımının yaygınlaşmasını sağlamış ve bugünkü seviyeye gelinmiştir. Olgun peynir sınıfında yer alan Kars kaşarı, dağ kaşarı olarak nitelenmektedir. Genel özellikleri korunmakla birlikte kaşar üretim alanlarına bağlı olarak birtakım değişiklikler de görülmektedir. Kars kaşarını diğer olgun peynirlerden ayırt eden temel özellikler iklime bağlı olarak şu şekilde açıklanmaktadır:

Peynirin yapımında kullanılan süt, 1600 civarında çiçekli bitkinin bulunduğu ve bunlardan 80 civarında taksonun endemik, 20 civarında taksonun ise nadir olduğu Kars ve Ardahan ilindeki meralarda otlayan hayvanlardan elde edilmektedir. Kars kaşarı üretimi mevsimlik bir faaliyettir ve hayvanların mayıs-ağustos aylarında merada serbest dolaşımla beslendiği dönemde elde edilen sütlerden üretilmektedir. Söz konusu ürün, muadillerinden merada otlayan hayvanların sütüyle üretilmesi yönüyle ayrılmaktadır. Kars kaşarında tat, lezzet ve aroma profilini belirleyen ve muadillerinden ayırt eden aldehitler, ketonlar, esterler, yağ asitleri, terpenler ve hidrokarbonlardan 32 madde vardır (URL-3).

Kars yöresinde kış mevsiminin sert ve uzun geçmesiyle ilkbaharın gelmesi, hayvanların beslenmesi açısından yaz boyu süren bir ekosistemin oluşmasını sağlamaktadır. Böylece hayvanlar yaz boyu serbest bir şekilde otlaklarda dolaşabilmektedir. Mayıs-temmuz döneminde yapılan kaşar, yaz kaşarıdır. Ağustostan itibaren otların kuruyup havaların soğumasıyla birlikte 
hayvanlar ahırlarda şekerpancarı sapı, küspe, saman vb. ile beslenmeye başlar ve sütün kalitesi düşer. Yaz kaşarının rengi sarı olup üzerinde gözenekler oluşur. Dana kursağından yapılan doğal mayanın kullanıldığı kaşarın aromasını veren bu maya ve otun kokusudur. Soğuk hava depolarında +2-4 derece en az 45 gün bekletilen yaz kaşarı, eski kaşar sayılır. Tuz oranına göre kaşarın bir-iki yıl kullanım ömrü vardır. Yörede "tuz, peynirin sigortasıdır" ifadesi yaygın olarak kullanılmaktadır (Yıldız ve Yıldııım, 2011: 164; URL-1; URL-2). Kaşar, tuzlanma ve bekleme süresine göre eski ve taze kaşar olarak ikiye ayrılmaktadır. Kaşarın olgunlaşma süreci Tablo 1'de verilmiştir:

\begin{tabular}{|c|c|c|c|c|c|}
\hline \multirow[b]{2}{*}{ Parametre } & \multicolumn{5}{|c|}{ Olgunlagturma Sïresi (gin) } \\
\hline & 3 & 30 & 60 & 120 & 180 \\
\hline $\begin{array}{l}\text { Kunumadde (glourumadde/ } 100 \\
\text { g Kagar) }\end{array}$ & $54,5-58$ & $57-61$ & $58,5-63$ & $59,5-63$ & $60-63,5$ \\
\hline Tuz (g NaCl100g Kasar) & $2.3-3.1$ & $2,7-3,5$ & $28-3.5$ & $3,3-3,5$ & $3.4-3.5$ \\
\hline $\begin{array}{l}\text { Laktik Asit (g laktik asit } / 100 \\
\text { g Kagar) }\end{array}$ & $0,83-1,35$ & $1,05-1,61$ & $1.16-1.94$ & $1,42-2,29$ & $1.65-2.29$ \\
\hline $\begin{array}{l}\text { Protein (g protein } / 100 \mathrm{~g} \\
\text { Kagar) }\end{array}$ & $24,8-27$ & $25,5-28$ & $26,5-28,5$ & $26,5-28,5$ & $26,5-29$ \\
\hline Kül (g kñil/100 z Kagar) & $4,14,8$ & $4,5-4,9$ & $4,6-4,9$ & $4,6-5,2$ & $4,7-5.3$ \\
\hline $\begin{array}{l}\text { Yağ (g yag̀ } 100 \text { g Kuru } \\
\text { madde) }\end{array}$ & $43.1-46.86$ & $47,27-50,86$ & $48,1-51,3$ & $48,1-51,3$ & $48,1-52.35$ \\
\hline $\begin{array}{l}\mathrm{pH}(\% \mathrm{pH} 4,6 \text {-Cōzininir } \\
\text { Azot Topiam Azot) }\end{array}$ & $2.77 \cdot 3.66$ & $2.99-6.46$ & $3.37-7.95$ & $3,55-8,06$ & $3.59 \cdot 10.50$ \\
\hline
\end{tabular}

Tablo 1. Kaşarın Olgunlaşma Süreci (URL 3).

Yörede eski kaşarın daha makbul sayıldığı bilinmektedir. Eski kaşar, taze kaşara göre daha yağsız olup bu kaşarın tuz oranı yüksektir. Eski kaşarın dışında oluşan yeşil tabaka daha uzun süre kullanılmasını sağlar. Ayrıca taze kaşarın üç ay, eski kaşarın daha uzun süre saklanabilmesi diğer peynir türleri arasında üstünlük kazanmasını sağlamaktadır. Taze kaşarın fast food gıda hazırlanmasında yaygın olarak kullanılması geniş bir alanda talep ve tüketimine sebep olmaktadır. Kaşar, haşlanıp yoğrularak yapılan deliksiz ve bakterilerle olgunlaştırılan tipik bir peynir örneğidir (ilimsever, 2004: 65; Özbudak, 2008: 57; Sertaç vd., 2019: 36). Buna ek olarak taze kaşar ve eski kaşar arasındaki fark şu şekilde açıklanmaktadır:

Taze Kars kaşarı kalıptan çıktığı gün beyazımsı renkte iken, bir hafta içerisinde kabuk bağlayarak sarımsı bir renk almaktadır. Taze Kars kaşarının kesit yüzeyi beyazımsı bir renkte ve tadı hafif tuzlu yavan ve süt tadını andırmaktadır. Eski Kars kaşarının kabuğu grimsi bir renk almakta ve kesit yüzeyi sarımsı krem renginde olmaktadır. Olgunlaşma süresi uzadıkça yapısı sertleşir. Eski kaşarda proteoliz, glikoz ve lipolizin etkisiyle kendine has yoğun aroma oluşur. Kıvam olarak, ihtiva ettiği su oranı az olduğundan sertçe ta- 
nımlanır. Strüktür olarak kesit yüzeyinin düz ve pürüzsüz olması gerekmektedir (URL-1).

Özellikle büyükbaş hayvancılığa dayalı verimli kaşar üretimi, yöredeki sınırlı ekonomik faaliyetler açısından bir çıkış kapısı teşkil etmektedir. Bu yönde oluşan farkındalık, belirli bir süre ekonomik faaliyet açısından kesintiye uğrayan kaşarcılığı, 2000’lerden sonra yörede diğer süt ürünleriyle birlikte yaygıılaştırmıştır. Bugün marka değeri açısından da önemli bir noktada olan kaşar peyniri, bölge insanın sosyo-ekonomik hayatına katkı sağlamaktadır. Böylece, "hem kültürün yaşaması sağlanmış hem de damak tadı korunmuş ... ilerleyen teknoloji ile artık pazara çok daha kolay bir şekilde ulaşabilmekte ve tüketime sunulabilme" (Durusoy, 2017: 112) olanağı ortaya çıkmıştır.

Hayvancılık, süt ve süt ürünlerinin üretim, saklanma ve sunum özellikleri bakımından çağrışım düzeyinde Kars'la bütünleşmiş olan kaşara, yukarıda da ifade edildiği üzere, 12.10.2015 tarihinde Türk Patent Enstitüsü tarafından coğrafi işaret verilmiştir. Coğrafi işaret bir ürünün üretim yerini ve geleneksel üretim biçimini belirleyerek koruma altına almayı amaçlamaktadır. Kafkas Üniversitesi öğretim üyesi Prof. Dr. Mithat Durmuş'un (URL-4) verdiği bilgilere göre patent başvuru sürecinde üreticileri bilgilendirme başta olmak üzere, medya kaynaklarının kullanımı, tanıtım, tadım ve panalist eğitimi web sayfası ve karekod hazırlığı gibi çeşitli faaliyetlerle birlikte logo tasarım yarışması yapılmıştır. Yapılan yarışmada Kars kaşarı logosu belirlenmiştir:

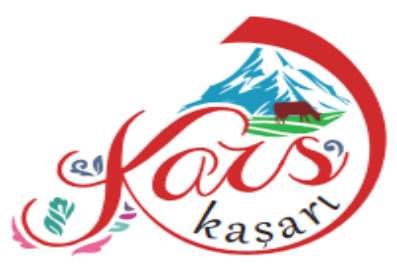

Görsel 2. Kars Kaşarı Logosu.

Durmuş, coğrafi işaret tescili sonrasında ortaya çıkan gelişmeleri, aynı yerden alıntıyla, pazarın yön değiş̧tirmesi, üretici ile tüketici arasında doğrudan bağ kurulmasının sağlanması, perakende satışlarda önemli bir artışın olması; üretim miktarı ve mandıra sayısındaki artış kaşar imalatının kış aylarında da devam etmesi, kaşarın yanı sıra, bal, tereyağı, kavılca, kaz eti gibi yöresel ürünlerin de pazarda yaygınlık kazanması ve turizm hareketleri ile üretici-tüketici arasındaki etkileşimin artması şeklinde sıralamaktadır. 
Kars kaşarının tanıtımı ve coğrafi işaret alma süreçlerinde Boğatape Çevre ve Yaşam Derneğinin yürüttüğü faaliyetler önemli bir etken olmuştur. Boğatepe köyü Türkiye'deki ilk peynir müzesi olma özelliğine sahip bir ekomüzeyi barındırmaktadır. Köyde 2009 yılında Malakanlardan kalan eski yapı onarılarak kurulan müze, üretim ve sunumla birlikte satış imkânına da sahiptir. "Müzede geçmişten günümüze peynirin üretim sürecinde nelere ihtiyaç duyulduğu sergilenmekte ve aynı zamanda da koruyup gelecek kuşaklara aktarılması sağlanmaktadır. Müze, bilgi birikiminin oluşmasına gıdanın üretim zincirini korumasına olanak sunmaktadır." (Atış ve Çelikoğlu, 2017: 321-322). Ekomüze anlayışı, fabrikasyon ürün ve üretim biçimi karşısında yerel unsurlara farkındalık kazandırma bakımından önemli bir etkendir.

Boğatepe Çevre ve Yaşam Derneği tarafından 5-7 Temmuz 2019 tarihleri arasında "Anadolu Peynirleri Kars Buluşması" etkinliği düzenlenmiştir. 2014'te "Alplerden Kafkaslara Kars Peynirciliğinin 150 Tarihi" adlı sergi ve kitap çalışmalarıyla başlayıp, 2016'da "Dünyada ve Türkiye'de YerelGeleneksel Peynirler: Kars Kaşarı Coğrafi Işsareti Uluslararası Sempozyumu", 2017'de "Kars Kaşarı'nın Duyusal Özelliklerinin Tanımlanması ve Olgunlaşma Performansının Değerlendirilmesi" ve 2018 yılında "Anadolu Peynirleri Kars'ta Buluşuyor!” başlıklarıyla yapılan etkinlikler, Anadolu Peynirleri Kars Buluşması 2019'la devam etmiştir (URL-5).

Coğrafi işaret alınmasıyla birlikte tanıtım faaliyetlerinin artması, kaşar üretimi ve pazarlanmasına da yansımıştır. Bu süreçte kaşarın üretiminde yapılan denetim, bir standardizasyonu sağlayarak ulusal ve uluslararası pazarda ortak bir algının şekillenmesini mümkün kılmıştır. Tüketicinin gözünde ürün imajının olumlu olması, coğrafi işaret tescilinin de etkisiyle sağlanmıştır. Bu sürecin ekonomik faydalarını gören üretici, coğrafi tescile tabi ürünün özelliklerinin korunmasına özen göstermektedir. Diğer taraftan ürünün özelliklerini tam olarak bilmeyen tüketici tarafından farklı algılanmaktadır. Özellikle ambalajsız satıldığında kaşarın dış kısmındaki renk değişimi dikkat çekmektedir. AB uyum süreciyle birlikte ortaya çıkan gıda ambalaj ve vakum kriterleri Kars kaşarı pazarını da etkilemiştir. Böylece hijyen ve sunum açısından daha uygun koşullar sağlanmaktadır. Öte yandan ekonomik değer artışıyla birlikte ortaya çıkan seri üretim ve fabrikasyon ürünün kalite kontrol süreçlerinin daha dikkatli yapılması gerekliliğini ortaya çıkarmıştır. Aksi takdirde kaşar kalitesindeki düşüş, markalaşma sürecine zarar verecek bu da geleneksel üreticiyi olumsuz etkileyecektir (Gelibolu, 2009: 163; Altunsabak, 2016: 47; Demir, 2016: 73). 
Turizm anlayışı bakımından dünyada ve Türkiye'de gelinen süreçte gastronomi turizmi önemli bir sosyo-ekonomik ve kültürel etkinlik alanına dönüşmüştür. Bu bağlamda kaşarın yöre adıyla özdeşleşmesi ve bir kent imgesine dönüşmesi, Kars'ın diğer hayvansal gıda ürünleriyle birlikte bir gastronomi turizmi sahasına dönüşmesini sağlamıştır. Peynir çeşitleriyle birlikte bal ve Kars kazı da yörede önemli bir ürün olarak görülmektedir. Bu süreç, yalnızca üretici açısından değil aynı zamanda yerel pazarlama ve taşıma ağı bakımından da faydalı sonuçlar doğurmaktadır. Ürünle birlikte üretim biçimi, üretim ortamı ve doğa, yerli ve yabancı turizm açısından cazip bir seçenek oluşturmuştur. Kars, çeşitli özellikleriyle bir ekoturizm alanı olarak dikkat çekmektedir (Karaca, 2016: 32-33; Durusoy, 2017: 219). Ankara-Kars arasında sefer yapan Doğu Expresi, bu süreçte Kars'a olan ilginin artmasındaki etkenlerden birisidir. Doğu Expresi'yle yapılan tren yolculuğu, kent ortamından sıkılan insanların doğa ve kültür bakımından yeni deneyimler edinmesini sağlamaktadır. Bu çerçevede Kars, cazip bir çevresel ve kültürel ekosistem teşkil etmektedir.

\section{Sonuç}

Küreselleşme ve kapitalizm karşısında gelenek kökenli kent imgeleri, kültürel direnç noktalarından birisini teşkil etmektedir. Kaşar, çağrışım yapacak seviyede Kars kentiyle özdeşleşmiş ve kent imgesine dönüşmüş bir hayvansal gıdadır. Tarih öncesinden bu yana insanın içinde yaşadığı doğal çevre; barınma ve giyim-kuşam kültürü kadar beslenme biçimlerini de şekillendirmiştir. Bu bağlamda Kars yöresi, iklim, yeryüzü şekilleri ve bitki örtüsüne bağlı olarak büyükbaş hayvancılığın yapıldığı bir bölgedir. Hayvansal ürünler yörenin beslenme alışkanlıklarında önemli bir yer tutmaktadır. Diğer taraftan bu ürünler, yöre ekonomisinde de önemli bir unsurdur. Makalede ele alınan kaşar peyniri, elde edilen bulgular ışığında, yörenin doğal yapısına bağlı olduğu kadar kültürel bir özelliğe de sahiptir. 19. yüzyılın sonundan bu yana yörede sürdürülen kaşar üretimi, Kars'ın kültürel belleğinin bir parçası haline gelmiştir. 2014 yılında yapılan başvuruyla 2015 yılında kaşar peynirinin Kars adına coğrafi işaret tescili alınmıştır. Bu tarihten itibaren yöredeki üretim, ticaret ve tanıtım etkinlikleri hız kazanmıştır. Konuyla ilgili konferanslar, paneller, tanıtım günleri düzenlenmiş; sempozyum ve Anadolu peynirleri buluşması etkinlikleri yapılmıştır. Ayrıca logo yarışması açılarak Kars kaşarının logosu belirlenmiştir.

Kars'la tarihsel ve kültürel olarak özdeşleşen kaşar, 2000'li yıllardan itibaren kent dışına yapılan sunum ve pazarlamayla birlikte bir tanıtım aracına dönüşmüştür. Bu durum makalede kent imgesi olarak değerlendirilmiştir. 
Kent imgeleri; çevresel, tarihî ve kültürel özellikleri "kentlerin dili" olarak ulusal ve uluslararası ortamda temsil eder. Bu temsilin, yöreye önemli sosyo-ekonomik ve kültürel yansımaları olur. Hayvansal bir gıda olan kaşar örneğinde olduğu gibi gastronomi turizmi alanında ortaya çıkan hareketlilik diğer yan alanlara da yansıyarak Kars'ın ekonomik faaliyetler bakımından canlanmasını sağlamaktadır. Özellikle kaşarın coğrafi işaret tescili sonrası Kars'a oluşan ilgili, bölgenin doğal zenginliklerine bağlı olarak bir ekoturizm alanına dönüşmesine de katkı sağlamaktadır. Bu durum kent imgelerinin öne çıkartılmasıyla kentin diğer özelliklerine de farkındalığın artmasına örnek teşkil etmektedir.

Batı ekonomik sistemlerinin dünyanın geri kalanına kültürel araçları da kullanarak hükmetme çabası şeklinde yorumlanabilecek olan küreselleşme, ülkelerin ve kentlerin tersine bir süreci işleterek kültür temelli ekonomik varlık göstermesine olanak sağlamaktadır. Ulaşım ve iletişim sistemlerinin gelişmesine bağlı olarak ortaya çıkan bu tersine etki; kent imgeleri vasıtasıyla hızlanmakta ve yaygınlaşmaktadır. Bu yaklaşım çerçevesinde makalede gelenek kökenli yöresel unsurların kent imgesine dönüşüm örneği olarak ele alınan Kars kaşarının, yan ürünleriyle birlikte yörenin kültür ekonomisine önemli katkı sağladığı görülmüştür. İnsanın doğaya olan ihtiyaç ve beklentileri ekolojik yaşam tarzı arzusunu daima canlı tutmaktadır. Bu bağlamda çevresel ve kültürel etkileşimle ortaya çıkan kent imgeleri, Kars kaşarı örneğinde olduğu gibi, bu ihtiyaçlara cevap verecek mikro alanlar sunmaktadır. Sonuç olarak kent odaklı halk bilimi çalışmalarının, gelenek kökenli kültürel unsurlara farkındalık oluşturma ve imge araştırmalarına veri sağlama açısından önemini yinelemek yerinde olacaktır.

\section{Kaynakça}

Altunsabak, Ergin (2016). Somut Olmayan Kültürel Mirasın Kuşaktan Kuşağa Aktarımı ve Gençlik; Kars ili Örneği. Yüksek Lisans Tezi. Ankara: Gazi Üniversitesi Sosyal Bilimler Enstitüsü.

Atış, Evren ve Çelikoğlu, Şaban (2017). "Boğatepe Köyünde Geleneksel Kars Gravyer ve Kaşar Peyniri Üretiminin Yöre Ekonomisi ve Tanıtımına Katkısı". Türk Coğrafya Kurumu 75. Kuruluş Yılı Uluslararası Kongresi. Ed. Ahmet Ertek vd. İstanbul: Türk Coğrafya Kurumu Yayınları, 310-324.

Barthes, Roland (1993). Göstergebilimsel Serüven. Çev. Mehmet Rifat ve Sema Rifat. İstanbul: Yapı Kredi Yayınları. 
Demir, Mucip (2016). "Coğrafi İşaret Örneği Olarak Kars Kaşar Peynirinin Üretimi ve Dağılımı”. Kafkas Üniversitesi Sosyal Bilimler Enstitüsü Dergisi, Ek Sayı 1: 61-81.

Dokuzlu, Sertaç vd. (2019). TRA2 Yöresi Yöresel Ürün Pazarlama Stratejileri. Kars: Serhat Kalkınma Ajansı.

Dundes, Alan (1998). “Halk Kimdir?”. Çev. Metin Ekici. Milli Folklor, 37: 139153.

Durukan, Arzu (2013). Kars ve Çevresinde Yaşayan Kültürlerin Ortak Gıda Alışkanlıkları ve Mizah. Doktora Tezi. İstanbul: Yeditepe Üniversitesi Sosyal Bilimler Enstitüsü.

Durusoy, Yalçın Yaman (2017). Coğrafi Işaretli Gastronomik Ürünlerin Bölge Halkı Tarafından Algılanması Üzerine Analitik Bir Araştırma: Kars Kaşarı Örneği. Doktora Tezi. i̇stanbul: Haliç Üniversitesi Sosyal Bilimler Enstitüsü.

Fidan, Süleyman ve Özcan, Fatma (2019). "Gastronomi Kenti Gaziantep’te Özel Gün Yemekleri Üzerine Bir Araştırma”. Uluslararası Sosyal Araştırmalar Dergisi, 12(67): 65-80.

Gelibolu, Levent (2009). "Kars Kaşar Peyniri iş̧letmelerinin Pazarlama Sorunları ve Çözüm Önerileri Üzerine Bir Alan Araştırması”. Atatürk Üniversitesi iiBF Dergisi, 23(3): 151-167.

Güzel, Cavit ve Kuşdemir, Orhan Fatih (2018). "Bir Kent Imgesi Olarak Amasya Elması". Dede Korkut Uluslararası Türk Dili ve Edebiyatı Araştırmaları Dergisi, 7(17): 206-221.

ilimsever, Zerican (2004). “Kars'ın Kaşar Peyniri”. Kentler ve Imgeler. Haz. M. Öcal Oğuz ve Tuba Saltık Özkan. Ankara: Gazi Üniversitesi Fen Edebiyat Fakültesi Gazi Türk Halkbilimi Topluluğu (GTHT) Yayınları, 65-67.

Karaca, Oya Berkay (2016). "Geleneksel Peynirlerimizin Gastronomi Turizmindeki Önemi”. Journal of Tourism and Gastronomy Studies, 4(2): 1739.

Keleş, Ruşen (1980). Kentbilim Terimler Sözlüğ̈̈. Ankara: TDK.

Kırzıoğlu, M. Fahrettin (1958). Kars Tarihi-1. İstanbul: Işıl Matbaası.

Kuzay Demir, Gonca (2015). "Kent İmgelerinin Değerlendirilmesi Bakımından Manisa". CBU Sosyal Bilimler Dergisi, 13(1): 500-512.

Lynch, Kevin (2014). Kent Imgesi. Çev. İrem Başaran. İstanbul: Türkiye iş̧ Bankası Kültür Yayınları. 
Nahya, Z. Nilüfer (2012). "Gaziantep’te Bir Kültürel Mekân Olarak Mutfak". Folklor/Edebiyat, 69: 9-24.

Oğuz, M. Öcal (2002). Küreselleşme ve Uygulamalı Halkbilimi. Ankara: Akçağ Yayınları.

Oğuz, M. Öcal (2004). "Önsöz”. Kentler ve imgeler. Haz. M. Öcal Oğuz ve Tuba Saltık Özkan. Ankara: Gazi Üniversitesi Fen Edebiyat Fakültesi Gazi Türk Halkbilimi Topluluğu (GTHT) Yayınları, 4.

Özbudak, Sibel (2008). Taze Kaşar Peyniri Üretiminde Haccp Güvenlik Sisteminin Kurulması. Yüksek Lisans Tezi. Tekirdağ: Namık Kemal Üniversitesi Fen Bilimleri Enstitüsü.

Özdemir, Nebi (2011). "Kentlerin Gezgin İmgeleri veya Kent Imgeleri Giydirilen Otobüsler". Millî Folklor, 89: 41-53.

Özdemir, Nebi (2012a). Kültür Ekonomisi ve Yönetimi (Seçki). Ankara: Hacettepe Yayıncılık.

TDK (2005). Türkçe Sözlük. Ankara: Türk Dil Kurumu Yayınları.

Yıldız, Sebahattin ve Alp, Salih (2014). "Bir Kümelenme Örneği Olarak Kars Kaşar Peyniri Endüstri Kümesi”. H.Ü. Iktisadi ve idari Bilimler Fakültesi Dergisi, 32(1): 249-272.

Yıldız, Sebahattin ve Yıldıım, Bahadır F. (2011). "Kars ilinde Kaşar Ticareti Yapan Firmaların Uyguladıkları Rekabet Stratejilerinin Belirlenmesi Üzerine Bir Araştırma”. Kafkas Üniversitesi Sosyal Bilimler Enstitüsü Dergisi, 7: 147-166.

\section{internet Kaynakları}

URL-1: www.kulturportali.gov.tr/turkiye/kars/kulturatlasi/kars-kasari (Erişim: 21.02.2021).

URL-2: www.kulturportali.gov.tr/turkiye/kars/nealinir/kars-kasari-ve-bali (Erişim: 21.02.2021).

URL-3: https://www.turkpatent.gov.tr/TURKPATENT/resources/temp/A9F5 4D9E-89D3-4EE9-9C27-B28FE3A8BE63.pdf;jsessionid=13DE27A2983 C65868571908B3E6F9FB9 (Erişim: 21.02.2021).

URL 4: https://www.ci.gov.tr/uploads/files/Mitat\%20\%C5\%9Eahin\%202.pdf (Erişim: 07.03.2021).

URL 5: https://www.sivilsayfalar.org/2019/07/17/bogatepe-cevre-ve-ya sam-dernegi-anadolu-peynirleri-kars-bulusmasini-duzenledi/ (Erişim: 07.03.2021). 
URL 6: https://online.turkpatent.gov.tr/trademark-search/pub/\#trade mark_result_detail (Erişim: 09.03.2021).

\section{Ek. Fotoğraflar}
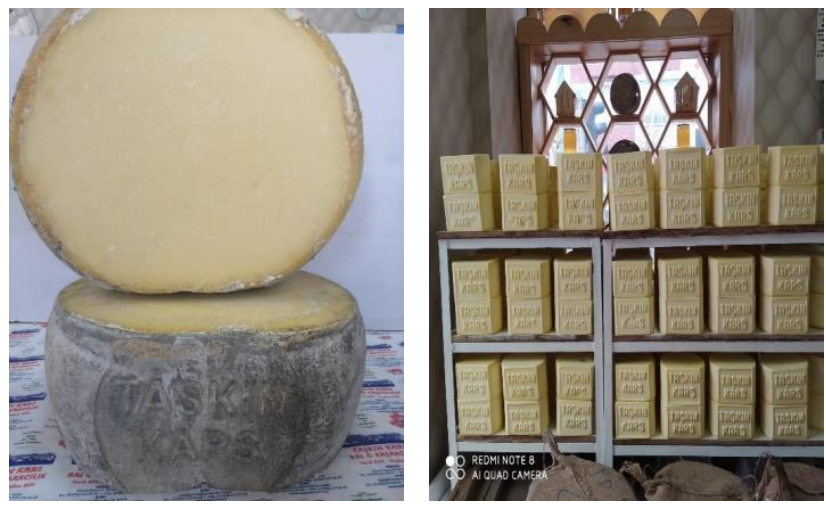

Fotoğraf 1, 2. Kars Kaşarı (Tarık Boy Arşivi).
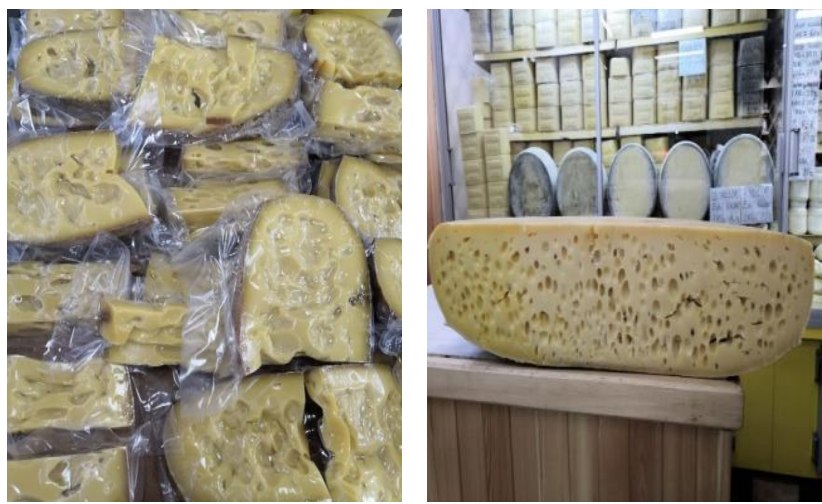

Fotoğraf 3, 4. Kars Kaşarı (Tarık Boy Arşivi).

"COPE-Dergi Editörleri İçin Davranış Kuralları ve En İyi Uygulama ilkeleri” çerçevesinde aşağıdaki beyanlara yer verilmiştir:

Etik Kurul Belgesi: Bu çalışma için etik kurul belgesi gerekmemektedir.

Çıkar Çatışması Beyanı: Bu makalenin araştırması, yazarlığı veya yayınlanmasıyla ilgili olarak yazarın potansiyel bir çıkar çatışması yoktur.

The following statements are made in the framework of "COPE-Code of Conduct and Best Practices Guidelines for Journal Editors":

Ethics Committee Approval: Ethics committee approval is not required for this study.

Declaration of Conflicting Interests: The author has no potential conflict of interest regarding research, authorship or publication of this article. 